\title{
Effect of Humic Acid and Molybdate on Phosphate Adsorption in Typic Hapludult of Cigudeg, Bogor
}

\author{
Heri Wibowo $^{1 *}$, Benito Heru Purwanto ${ }^{2}$, and Supriyanto Notohadisuwarno ${ }^{2}$ \\ ${ }^{1}$ Indonesian Soil Research Institute, Indonesian Agency for Agricultural Research and Development \\ Jl. Tentara Pelajar No. 12, Ciwaringin, Bogor Tengah, Kota Bogor, Jawa Barat 16114, Indonesia \\ ${ }^{2}$ Department of Soil Science, Faculty of Agriculture, Universitas Gadjah Mada \\ Jln. Flora no. 1, Bulaksumur, Sleman, Yogyakarta 55281, Indonesia \\ *Corresponding email: masherizal@gmail.com
}

Received: $8^{\text {th }}$ December 2017 ; Revised: $19^{\text {th }}$ March 2017 ; Accepted: $29^{\text {th }}$ December 2017

\begin{abstract}
Humic acids containing carboxyl and hydroxyl groups that have the ability to cover the $\mathrm{P}$ adsorption site in Typic Hapludults. Molybdate has similarity behaviour with phosphate in theacid soils. Research aim was to study the effects of molybdate and humic acid to the kinetics of phosphate adsorption in Typic Hapludults of Cigudeg, Bogor. Important of kinetics is to get accuration of materials transport, to control influence on anion mobility, that the assessment is needed for the efficient application of Mo and P. Aplication humic acid and molybdate as competitor anion of phosphate was conducted with combination of humic acid and Mo concentration as double anions. Many models describe the kinetics for the adsorption of phosphate by soils i.e. zero order, first order, second order, and Elovich. As ststistically, there was not interaction of humic acid and molybdate on P adsorption. Application of humic acid with rate of $100 \mathrm{mg}$. $\mathrm{L}^{-1} \mathrm{was}$ not effective decrease $\mathrm{P}$ adsorption in Typic Hapludults. It was due to the $\mathrm{pH}$ of the adsorption system that get near to its pKa of carboxyl gruop about 5. Meanwhile aplication 2 and $5 \mathrm{mmol} . \mathrm{L}^{-1}$ of molybdate significantly decrease of $\mathrm{P}$ adsorption. The second order kinetics models apropriate to the adsorptionof $\mathrm{P}$ in the Typic Hapludults of Cigudeg, with determination coefficients value $\left(\mathrm{R}^{2}\right)$ of $0.999-1$ and standard error value (SE) of $0.001-0.011$. The results suggest that the molybdate as competitor anion affected the kinetics for the adsorption of phosphate due to the charge of molybdate.
\end{abstract}

Keywords: Humic Acid, Kinetics Models, Molybdate, P Adsorption, Second Order

\section{INTRODUCTION}

In the development of agricultural commodities in acid soils will face various technical problems such as low level of soil fertility and water availability in the dry season for dry land. Some of the characteristics of acid soils include the nature of acid soil reactions (low $\mathrm{pH}$ ) associated with high $\mathrm{Al}$ content, high $\mathrm{P}$ fixation, low exchangeable base content, iron and manganese content close to the toxic limit of plants, and low availability of micro nutrients. Adsorption of molybdate in the soil is positively correlated with concentrations of $\mathrm{Fe}$ and $\mathrm{Al}$ oxides are particularly prone to Mo deficiency (Mengel et al., 2001). The characteristics that become obstacles in the management of acid soilcan be overcome by fertilizing technology, liming, and management of organic materials. Addition of humic acid can increase the availability of $\mathrm{P}$, able to reduce the solubility of $\mathrm{Al}$ and $\mathrm{Fe}$ on acid soils (Ifansyah, 2013).

Phosphorus $(\mathrm{P})$ is one of most needed nutrient by plant, major essential plant elements. It have function as a component of certain enzymes and proteins, adenosine triphosphate (ATP), ribonucleic acids (RNA), deoxyribonucleic acids (DNA), and phytin. Where ATP is involved in various energy transfer reactions, and RNA and DNA are components of genetic information (Jones, 2012). Meanwhile as essential element, Molybdenum (Mo) have important role in the biogeochemical cycle of nitrogen $(\mathrm{N})$. It have functions in plant as a component of two major enzyme systems, nitrogenase and nitrate reductase, nitrogenase being involved in the conversion of nitrate $\left(\mathrm{NO}_{3}\right)$ to ammonium $\left(\mathrm{NH}_{4}\right)$. The requirement for Mo is reduced greatly if the primary form of nitrogen (N) available to the plant is $\mathrm{NH}_{4}$ (Jones, 2012). 
Molybdate has similarity behaviour with phosphate or sulphate in the soil. Adsorption of molybdate by sequioxides and clay minerals has analogous way to phosphate. Highly weathered soils, like Ultisols and Oxisols containing large amount of amorphous and crystalline $\mathrm{Fe}$ oxide minerals. Where adsorption of molybdate is affected by concentrations of $\mathrm{Fe}$ and $\mathrm{Al}$ oxides (Mengel et al., 2001). Thus, $P$ and Mo deficiencies often occur in highly weathered acid soils (Vistoso et al., 2009). Soil adsorption properties can cause nutrient deficiencies in the soil, that can be avoided by proper fertilization of dose and time of application. It is therefore important to know the adsorption kinetics of nutrient in the soil.

The need for kinetics is to know accurately both the accumulation and transportation of materials (Sparks, 2012), to control influence on anion mobility, transport, and bioavailability (Vistoso et al., 2009), that the assessment is needed for the efficient application of Mo and P fertilizers. Many models describe the kinetics for the adsorptionof phosphate by soils i.e. zero order, first order, second order, Elovichwhich were described as Eqs (1), (3), (4), and (6) (Vistoso et al., 2009); (Sparks, 2012); (Huang et al., 2015). The zero order equation is expressed as follow equations:

$$
q_{t}=q_{0}-k_{0} t
$$

Here $\mathrm{q}_{\mathrm{t}}$, and $\mathrm{q}_{\mathrm{o}}$ denote the quantity at time $(\mathrm{t})$ and time zero, where $\mathrm{k}_{\mathrm{o}}$ is the rate constant of zero order sorption. The first order equation is generally expressed as follows:

$$
\frac{d q_{e}}{d t}=k_{1}\left(q_{e}-q_{t}\right)
$$

After integration and applying the boundary conditions, for $\mathrm{q}_{\mathrm{t}}=0$ at $\mathrm{t}=0$ and $\mathrm{q}_{\mathrm{t}}=\mathrm{q}_{\mathrm{t}}$ at $\mathrm{t}=\mathrm{t}$, the integrated form of Eq. (2) becomes:

$$
\log \left(q_{e}-q_{t}\right)=\log \left(q_{e}\right)-\frac{k_{1}}{2.303} t
$$

where $\mathrm{q}_{\mathrm{e}}$ and $\mathrm{q}_{\mathrm{t}}$ are the amounts of phosphates adsorbed at equilibrium and at time $t$, respectively, and $k_{1}$ is the rate constant of first order adsorption. If the rate of adsorption is a second order mechanism, the second order kinetic rate equation is expressed as:

$$
\frac{t}{q_{t}}=\frac{1}{k_{2} q_{e}^{2}}+\frac{1}{q_{e}} t
$$

where $\mathrm{k}_{2}$ is the rate constant of second order sorption and $\mathrm{q}_{\mathrm{e}}$ is the amount of phosphates adsorbed at equilibrium. The Elovich equation is given as follows:

$$
\frac{d q_{t}}{d_{t}}=\alpha e^{-\beta q_{t}}
$$

The integration of the rate equation with the same boundary conditions as the first and second order equations becomes the Elovich equation:

$$
q_{t}=\frac{1}{\beta} \ln (\alpha \beta)+\frac{1}{\beta} \ln (t) .
$$

where $\alpha$ is the initial sorption rate, and the parameter $\beta$ is related to the extent of surface coverage and activation energy for chemisorption. The aim of this research was to compare the effect of the persence of humic acid and molybdenum on the phosphate adsorption in acid soil.

\section{MATERIALS AND METHODS}

Typic Hapludults was taken from Cigudeg, Bogor district, province of Jawa Barat. Soil $\mathrm{pH}$ was measured in water using soil suspensions at a soil:solution ratio of 1:5. Organic carbon and humic carbon was measured with Walkley and Black titration method meanwhile total $\mathrm{N}$ with Kjeldahl method. Total and available phosphate were extracted with wet combustion $\mathrm{HNO}_{3}-\mathrm{HClO}_{4}$ and Bray 1, respectively and measured colourimetrically measured at $889 \mathrm{~nm}$ in a spectrophotometer. Total Mo was extracted with wet combustion $\mathrm{HNO}_{3}-\mathrm{HClO}_{4}$ and measured by AAS. Exchangeable base cations $(\mathrm{Ca}, \mathrm{Mg}, \mathrm{K}, \mathrm{Na})$ were extracted with $1 \mathrm{M} \mathrm{NH}_{4} \mathrm{Cl}$ and analyzed using atomic absorption spectrophotometry (AAS) for $\mathrm{Ca}$ and $\mathrm{Mg}$, flamephotometer for $\mathrm{K}$ and $\mathrm{Na}$. Al-p and Fe-P measured by Chang and Jaction methods. Exchangeable aluminium was extracted with $1 \mathrm{M}$ $\mathrm{KCland}$ analyzed by titrition. And the cation exchange capacity (CEC) was extracted with $1 \mathrm{M} \mathrm{NH}_{4} \mathrm{Cl}$, and measured by distillation process with Kjeldahl method (Balai Penelitian Tanah, 2009).

Humic acid was produced by mix a weighed amount of cow manure compost (pass a 2-mm sieve) with a $0.1 \mathrm{M}$ solution of $\mathrm{NaOH}$ at a soil/solution ratio of 1:10 and shaked it continuously overnight (IHSS, no date). The supernatant, containing fulvic acid and humic acid, was separated from the precipitate as humin. Further, supernatant was acidified to $\mathrm{pH}$ 2.0 by adding drops of $\mathrm{HCl}$ to precipitate the humic acid fraction. The supernatant, containing fulvic acid, is then separated from the precipitate as humic acid (Tan, 2014).

Persence effect of humic substance and molybdenum to the adsorption kinetics of the soil to the phosphorus were obtained in batch systems using a soil:solution ratio of 1:20 with $0.1 \mathrm{M} \mathrm{KCl}$ as background electrolyte at an initial $\mathrm{pH}$ of 5.0. For the competitive adsorption 
studies the initial humic substance concentrations were 0 and $100 \mathrm{mg} . \mathrm{L}^{-1}$ while molybdate $\left(\mathrm{Na}_{2} \mathrm{MoO}_{4} \cdot 2 \mathrm{H}_{2} \mathrm{O}\right)$ concentrations were 0,2 , and 5 mmol. $\mathrm{L}^{-1}$ as $\left(\mathrm{Mo}_{0}, \mathrm{Mo}_{2}\right.$, and $\left.\mathrm{Mo}_{5}\right)$, and each of these concentrations were tested with 0,1 and 2 mmol. $\mathrm{L}^{-1}$ phosphate $\left(\mathrm{K}_{2} \mathrm{HPO}_{4}\right)$ as $\left(\mathrm{P}_{0}, \mathrm{P}_{1}\right.$, dan $\left.\mathrm{P}_{2}\right)$ (Vistoso et al., 2012). So there were 18 combination treatments of humic, phosphate, and molybdate i.e. $\mathrm{P}_{0} \mathrm{Mo}_{2}, \mathrm{H}-$ $\mathrm{P}_{0} \mathrm{Mo}_{2}$, and etc. Samples were weighed and placed in polypropylene tubes, and the suspensions were shaken in an end-over-end shaker for $2 \mathrm{~h}$ at ambient temperature. The soil suspensions were then filtered with Whatman 42, aliquots of the supernatants were taken for analysis. P was determined by the phosphomolybdate-ascorbic acid method (Sadzawka et al. 2006). The amount of anion sorbed was derived from the difference between the initial and final solution concentrations. The experimental data were statistically analyzed using SPSS 16 version for windows. Appropriate adsorption kinetic model was evaluated by the determination coefficient $\left(\mathrm{R}^{2}\right)$ and standard error (SE) of (Dong, 2016). The values of $\mathrm{R}^{2}$ and SE were used to compare the applicability of the different models at a confidence level of $95 \%$.

\section{RESULT AND DISCUSSION}

Chemical properties of experiment soil were shown in Table 1. Used soil has characteristics as acidic soil with $\mathrm{pH} 4.62$. Soil has moderate $\mathrm{C}$ content about $2.23 \%, 0.0632 \%$ humic carbon, and total nitrogen was low $(0.16 \%)$. So $\mathrm{C} / \mathrm{N}$ ratio was 13.82 and categorized as moderate level. High total $\mathrm{P}$ concentrations about $274.15 \mathrm{mg} \cdot \mathrm{kg}^{-1} \mathrm{P}_{2} \mathrm{O}_{5}$, but with low availability of $\mathrm{P}$ about $3.73 \mathrm{mg} \cdot \mathrm{kg}^{-1}$, this is in accordance with the acidic soil reaction that cause the low availability of P. Futhermore high total Fe about $813.79 \mathrm{mg} . \mathrm{kg}^{-1}$ and total $\mathrm{Al}$ about $47 \mathrm{mg} \cdot \mathrm{kg}^{-1}$ would decrease availability of P. Soil contain of $25.6 \mathrm{mg} \cdot \mathrm{kg}^{-1} \mathrm{Al}-\mathrm{P}, 20.1 \mathrm{mg} \cdot \mathrm{kg}^{-1}$ of Fe-P, and $3.8 \mathrm{mg} \cdot \mathrm{kg}^{-1}$ of Mo. Soil cation exchange capacity (CEC) scored as moderate level, i.e. 16.85 $\mathrm{cmol}(+) \cdot \mathrm{kg}^{-1}$ with very low base saturation value of 13.83. The soil was classified as Typic Hapludult (Badan Penelitian dan Pengembangan Pertanian, 2014); supported with the soil characteristics of clay texture, acidic reaction, moderate score CEC, and very low base saturation (USDA, 2014). The soil was red colour, high degree of soil development and high significant clay accumulation in the soil. It was detected the texture class of clay with $1.49 \%$ sand, $6.56 \%$ silt, and $91.95 \%$ clay (IUSS Working Group WRB, 2014).

Another identification of the soil was clay content
Table 1. Chemical properties of Cigudeg Typic Hapludult

\begin{tabular}{|c|c|c|c|}
\hline Parameter & Unit & Value & Score* \\
\hline \multicolumn{4}{|l|}{ Texture } \\
\hline Sand & $\%$ & 1.49 & clay \\
\hline Silt & $\%$ & 6.56 & \\
\hline Clay & $\%$ & 91.95 & \\
\hline $\mathrm{pH}\left(\mathrm{H}_{2} \mathrm{O} \quad 1: 5\right)$ & & 4.62 & acidic \\
\hline Total N & $\%$ & 0.16 & low \\
\hline Org-C & $\%$ & 1.65 & moderate \\
\hline $\mathrm{C} / \mathrm{N}$ & & 13.82 & moderate \\
\hline BO & $\%$ & 3.85 & \\
\hline P Bray 1 & $\mathrm{mg} \mathrm{kg}^{-1}\left(\mathrm{P}_{2} \mathrm{O}_{5}\right)$ & 3.73 & very low \\
\hline $\mathrm{P}\left(\mathrm{HClO}_{3} \& \mathrm{HNO}_{3}\right)$ & $\mathrm{mg} \mathrm{kg}^{-1}\left(\mathrm{P}_{2} \mathrm{O}_{5}\right)$ & 274.15 & \\
\hline \multicolumn{4}{|l|}{ Base cations } \\
\hline K & $\operatorname{cmol}(+) \mathrm{kg}^{-1}$ & 0.20 & low \\
\hline $\mathrm{Na}$ & $\operatorname{cmol}(+) \mathrm{kg}^{-1}$ & 0.17 & low \\
\hline $\mathrm{Ca}$ & $\operatorname{cmol}(+) \mathrm{kg}^{-1}$ & 1.12 & very low \\
\hline $\mathrm{Mg}$ & cmol (+) $\mathrm{kg}^{-1}$ & 0.99 & low \\
\hline Al-dd & $\operatorname{cmol}(+) \mathrm{kg}^{-1}$ & 1.37 & \\
\hline CEC & $\operatorname{cmol}(+) \mathrm{kg}^{-1}$ & 16.86 & moderate \\
\hline Base Saturaion & & 13.82 & very low \\
\hline Al-P & $\mathrm{mg} \mathrm{kg}^{-1}$ & 25.26 & \\
\hline Fe-P & $\mathrm{mg} \mathrm{kg}^{-1}$ & 20.10 & \\
\hline $\mathrm{Fe}$ & $\mathrm{mg} \mathrm{kg}^{-1}$ & 813.79 & \\
\hline $\mathrm{Al}$ & $\mathrm{mg} \mathrm{kg}^{-1}$ & 47.00 & \\
\hline Humic-C & $\%$ & 0.063 & \\
\hline $\mathrm{Mo}\left(\mathrm{HClO}_{3} \& \mathrm{HNO}_{3}\right)$ & $\mathrm{mg} \mathrm{kg}^{-1}$ & 3.8 & \\
\hline
\end{tabular}

Remarks: ** Score was based on (Balai Penelitian Tanah, 2009), $\mathrm{w} / \mathrm{w}=$ weight per weight.

identification by X-ray diffraction. Air dried treatment gave interlayer space about $7.3 \AA$ that show metahalloysite clay minerals, 4.17 and $3.54 \AA$ that show kaolinite clay minerals content. Heating with temperature of $550^{\circ} \mathrm{C}$ gave interlayer space about $2.7 \AA$ that show collapse or dissapear of the peak as characteristics of kaolinite and matahalloysite minerals. Clay treatment with $\mathrm{K}$ saturation gave interlayer space about $7.4 \AA$ as characteristics of the metahalloysite. Saturation of clay with Mg gave $7.19 \AA$ space interlayer asa characteristic of kaolinite clay minerals. Saturation by a cation makes it possible to fill the existing cation vacancies and, by displacement of the exchangeable cations, to obtain homoionic samples that present uniform expansion of the layers of the expansible phyllosilicates (the quantities of interlayer water depend on the exchangeable cations) (Pansu and Gautheyrou, 2006). According to (Pansu and Gautheyrou, 2006); (Tan, 2011) and with that characteristics, the soil contain of kaolinite and metahalloysite as clay 


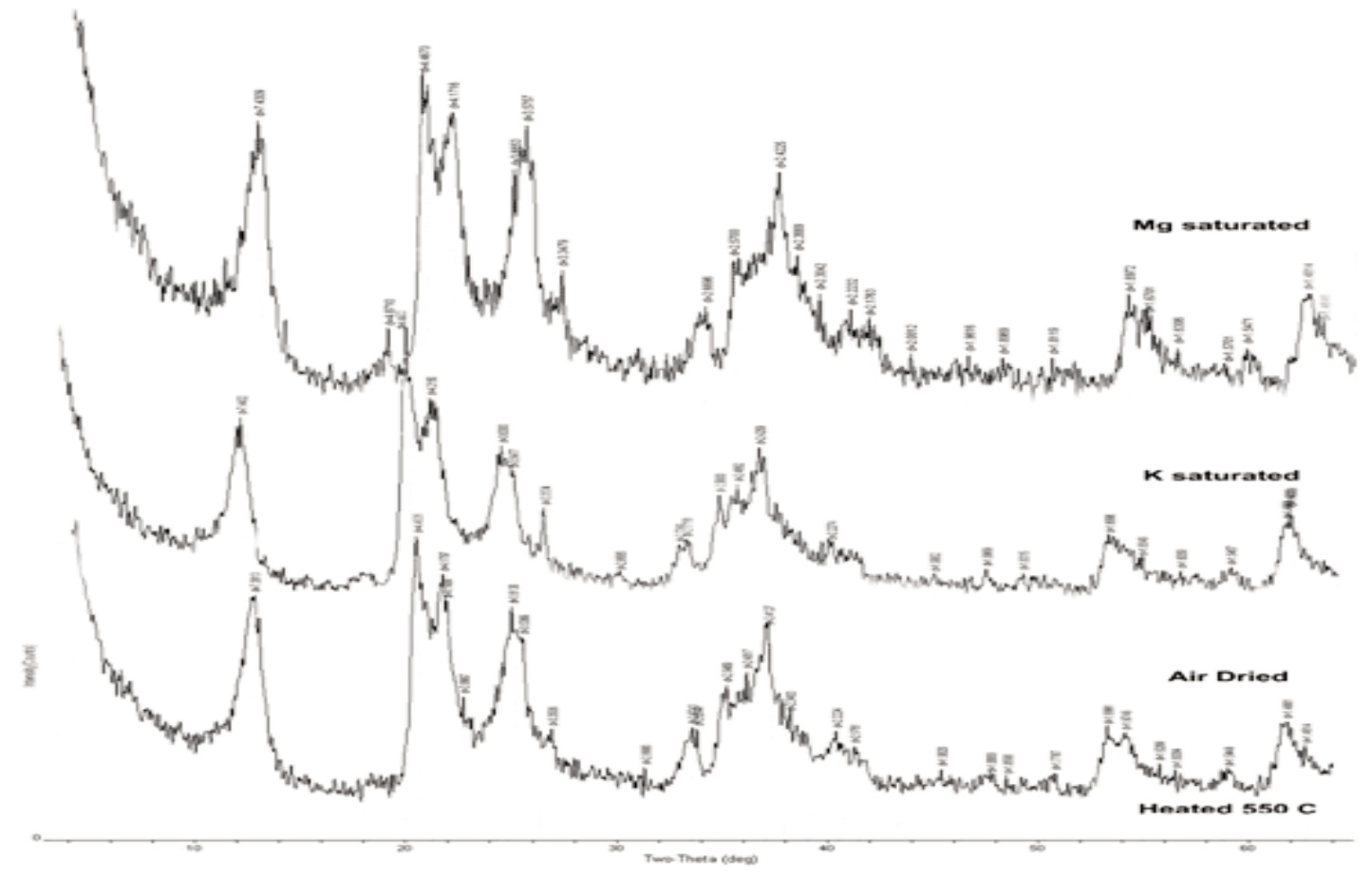

Figure 1. X-ray diffraction of clay minerals of Cigudeg Typic Hapludult

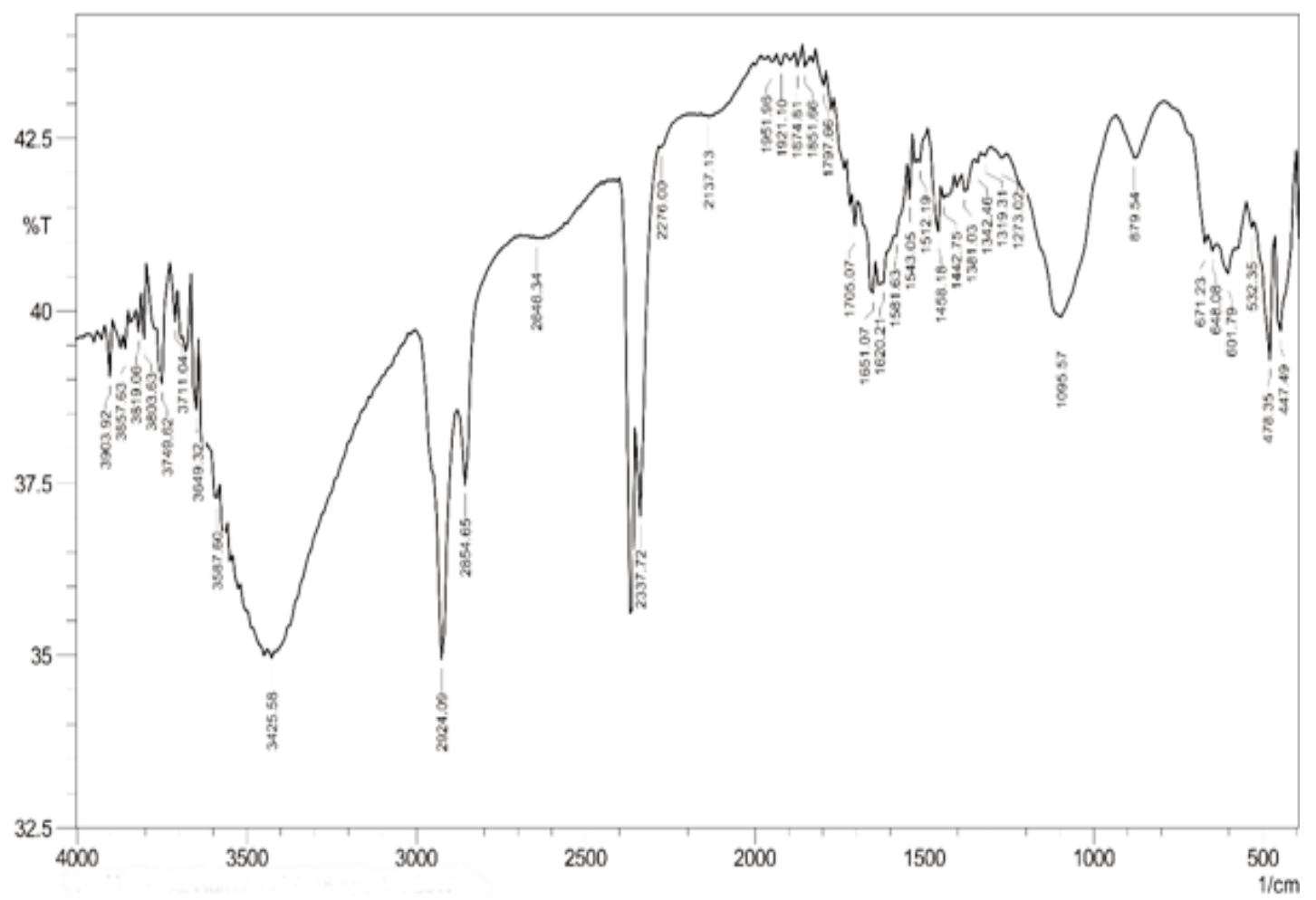

Figure 2. FTIR analysis of humic acid extraced from cow manure compost

minerals. The soil also contain of gibbsite, geothite and hematite as oxides and hydroxides and feldspar as silicates minerals. In the most highly weathered soils in the tropics such as Ultisols and Oxisols contain high concentration of hydroxide minerals, which are responsible for phosphorus adsorption (Kurnain, 2016).

The extraced humic acid contain of $56.4 \% \mathrm{C}$.
Humic acid is usually rich in carbon, which ranges from $41 \%$ to $57 \%$ (Tan, 2011). Steelink (Steelink, $1985)$ showed carbon content in humic acid reached $53.8 \%$ to $58.7 \%$. This indicates the occurrence of carbon fixation or retardation occurring during the synthesis of humic material and with the increased humidity rate. Decomposition of organic residues is generally characterized by the loss of $\mathrm{C}$ in the form 
Table 2. Effect of humic acid to the $\mathrm{P}$ adsorption of Cigudeg Typic Hapludult with initial $\mathrm{P}$ of $1 \mathrm{mmol} \mathrm{L}^{-1}$

\begin{tabular}{|c|c|c|c|c|c|c|c|c|c|}
\hline \multirow{3}{*}{$\begin{array}{c}\text { Adsorption } \\
\text { Time } \\
\text { (minute) }\end{array}$} & \multicolumn{9}{|c|}{ Adsorbed $\mathrm{P}(\mathrm{mg} \mathrm{kg}-1)$ with initial $\mathrm{P}$ of $1 \mathrm{mmol} \mathrm{L}^{-1}$} \\
\hline & \multicolumn{3}{|c|}{ Mo of $0 \mathrm{mmol} \mathrm{L}^{-1}$} & \multicolumn{3}{|c|}{ Mo of $2 \mathrm{mmol} \mathrm{L}^{-1}$} & \multicolumn{3}{|c|}{ Mo of $5 \mathrm{mmol} \mathrm{L}^{-1}$} \\
\hline & $\begin{array}{l}\text { Non- } \\
\text { Humic }\end{array}$ & Humic & sig & $\begin{array}{c}\text { Non- } \\
\text { Humic }\end{array}$ & Humic & sig & $\begin{array}{c}\text { Non- } \\
\text { Humic }\end{array}$ & Humic & sig \\
\hline 20 & 90.2506 & 87.0229 & 0.443 & 84.7188 & 89.1385 & 0.256 & 84.2100 & 86.9400 & $\left.0.366^{*}\right)$ \\
\hline 40 & 92.6151 & 92.4557 & 0.715 & 90.3927 & 90.8693 & 0.590 & 87.7867 & 88.5133 & 0.505 \\
\hline 60 & 93.3578 & 92.9096 & 0.534 & 91.2499 & 91.2646 & 0.954 & 88.8233 & 88.3967 & 0.637 \\
\hline 80 & 93.8527 & 93.4855 & 0.503 & 91.6394 & 91.5810 & 0.737 & 89.3733 & 89.2600 & 0.854 \\
\hline 100 & 93.9917 & 93.9709 & 0.940 & 92.2226 & 92.1876 & 0.854 & 89.9133 & 89.4833 & 0.413 \\
\hline 120 & 93.9547 & 93.2440 & 0.377 & 92.5616 & 90.0085 & 0.344 & 89.8933 & 88.3967 & 0.442 \\
\hline
\end{tabular}

Remarks: *) significant difference at sig $\leq .05$

Table 3. Effect of humic acid to the $\mathrm{P}$ adsorption of Cigudeg Typic Hapludult with initial $\mathrm{P}$ of $2 \mathrm{mmol} \mathrm{L}^{-1}$

\begin{tabular}{cccccccccc}
\hline \multirow{2}{*}{\begin{tabular}{c} 
Adsorption $\begin{array}{c}\text { Time } \\
\text { (minute) }\end{array}$ \\
\cline { 2 - 11 }
\end{tabular}} & \multicolumn{3}{c}{ Mo of 0 mmol L-1 } & \multicolumn{1}{c}{ Adsorbed P $(\mathrm{mg} \mathrm{kg}-1)$ with initial P of $2 \mathrm{mmol} \mathrm{L}^{-1}$} \\
& $\begin{array}{c}\text { Numic } \\
\text { Humic }\end{array}$ & sig & $\begin{array}{c}\text { Non- } \\
\text { Humic }\end{array}$ & Humic & sig & $\begin{array}{c}\text { Non- } \\
\text { Humic }\end{array}$ & Humic & sig \\
\hline 20 & 167.58 & 166.74 & 0.923 & 161.11 & 160.59 & 0.925 & 159.28 & 159.08 & $0.909 *)$ \\
40 & 169.90 & 176.00 & 0.339 & 167.05 & 171.75 & 0.058 & 164.57 & 164.02 & 0.936 \\
60 & 176.32 & 178.29 & 0.326 & 171.55 & 172.64 & 0.507 & 167.47 & 164.70 & 0.729 \\
80 & 178.26 & 179.73 & 0.512 & 173.99 & 170.46 & 0.256 & 164.35 & 162.46 & 0.726 \\
100 & 180.11 & 180.52 & 0.743 & 175.12 & 175.18 & 0.960 & 168.90 & 168.67 & 0.968 \\
120 & 178.27 & 179.46 & 0.782 & 175.44 & 171.48 & 0.240 & 168.30 & 169.85 & 0.751 \\
\hline
\end{tabular}

Remarks: *) difference is significant at sig $\leq .05$

Table 4. Effect of molybdate persence to the adsorption of phosphate by Typic Hapludult of Cigudeg, Bogor.

\begin{tabular}{ccccccc}
\hline $\begin{array}{c}\text { Concentration of } \\
\text { Mo in soil solution } \\
\left(\mathrm{mmol} \mathrm{L}^{-1}\right)\end{array}$ & 20 & 40 & 60 & 80 & 100 & 120 \\
\cline { 2 - 7 } & $90.2506 \mathrm{a}$ & $92.6151 \mathrm{a}$ & $93.3578 \mathrm{a}$ & $93.8527 \mathrm{a}$ & $93.9917 \mathrm{a}$ & $\left.93.9547 \mathrm{a}^{*}\right)$ \\
2 & $84.7188 \mathrm{a}$ & $90.3932 \mathrm{~b}$ & $91.2499 \mathrm{~b}$ & $91.6394 \mathrm{~b}$ & $92.2226 \mathrm{~b}$ & $92.5615 \mathrm{~b}$ \\
5 & $84.2073 \mathrm{a}$ & $87.7886 \mathrm{c}$ & $88.819 \mathrm{c}$ & $89.3726 \mathrm{c}$ & $89.9112 \mathrm{c}$ & $89.8933 \mathrm{c}$ \\
\hline
\end{tabular}

Remarks: *) Column values followed by the same letter are not significantly different according to Duncan's multiple range test $(\mathrm{P}=0.05)$

of $\mathrm{CO}_{2}$. However, when humification occurs, some $\mathrm{C}$ will enter the humus and material humic. Nitrogen content in humic acid about $3.1 \%$ where the avverage nitrogen content in the soil humic acid were $2.6 \%$ to $5.05 \%$. (Steelink, 1985); (Tan, 2014)). According to other research, humic acid was extracted from the soil of a citrus orchard (Rhodoxeralf) (Basra, Israel) had elemental composition C 53.4\%; N 5.4\%; O 35.6\%; H 5.2\%; S 0.4\% (Chotzen et al., 2016).

Identification of humic acid with Infrared spectroscopy, there were about 40 peak in the Infrared spectra of extraced humic acid. Figure 2 shows that lots of in hydroxyl and carboxylic groups exist in humic acid, according to (Zhenghua et al., 2001) that were responsible for behavior adsorption. Strong absorption at $3,425 \mathrm{~cm}^{-1}$ show the $\mathrm{O}-\mathrm{H}$ and $\mathrm{N}-\mathrm{H}$ stretch, strong absorption at $2,924 \mathrm{~cm}^{-1}$ of $\mathrm{C}-\mathrm{H}$ stretch and $2855 \mathrm{~cm}^{-1}$ of aliphatic C-H stretch, strong absorption at $1651 \mathrm{~cm}^{-1}$ of $\mathrm{C}=\mathrm{O}$ stretch (amide $\mathrm{I}$ ). There were not absorption in $1000 \mathrm{~cm}^{-1}$, but were in $1095 \mathrm{~cm}^{-1}$ that show $\mathrm{C}-\mathrm{C}, \mathrm{C}-\mathrm{OH}, \mathrm{C}-\mathrm{O}-\mathrm{C}$ typical of glucosidic linkages, polymeric substances, and $\mathrm{Si}-\mathrm{O}$ impurities in humic compounds. Humic acid exhibits a strong absorption for C-H vibrations at 2980 to $2920 \mathrm{~cm}^{-1}$ (Maccarthy and Rice, 1985); (Tan, 2011), and a stronger absorption for both carbonyl and carboxyl vibrations in COO- form at 1,720 and 1,650 $\mathrm{cm}^{-1}$, respectively. Humic acid spectra have, in addition, no absorption bands at 1,000 $\mathrm{cm}^{-1}$ (Tan, 2011).

Strong $\mathrm{P}$ adsorption in acid soils such as Oxisols and Ultisols and in volcanic soils with andic properties is mainly caused by the presence of large hydrous Fe and Al surface areas in the soil (Rengel, 2003); (Anwar and Sudadi, 2013). The presence of a competitor, such as humic acid, reduces phosphate adsorption and reveals that both ions are in competition 


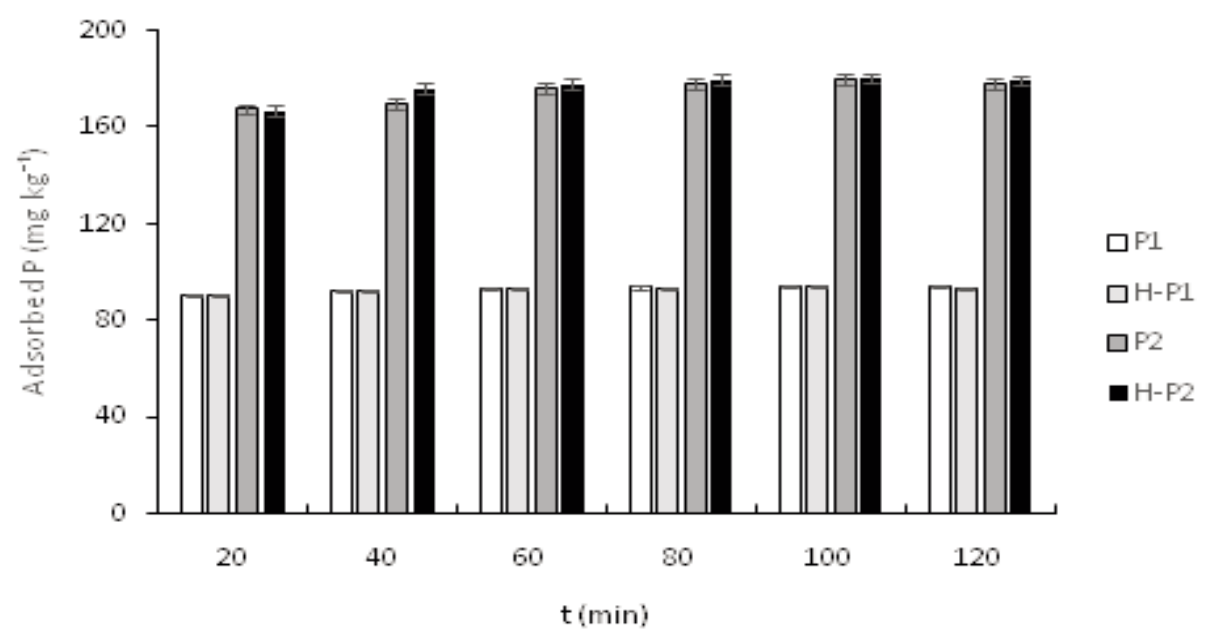

Figure 3. Effect humic acid substances aplication on the phosphate adsorptions in Typic Hapludult of Cigudeg. Bogor. P1 : initial P concentration of 1 mmol.L-1; H-P1 : aplication Humic acid with initial P concentration of $1 \mathrm{mmol} \mathrm{L}^{-1} ; \mathrm{P} 2$ : initial P concentration of 2 mmol.L $\mathrm{L}^{-1} ; \mathrm{H}-\mathrm{P} 2$ : aplication Humic acid with initial P concentration of 2 mmol. $\mathrm{L}^{-1}$
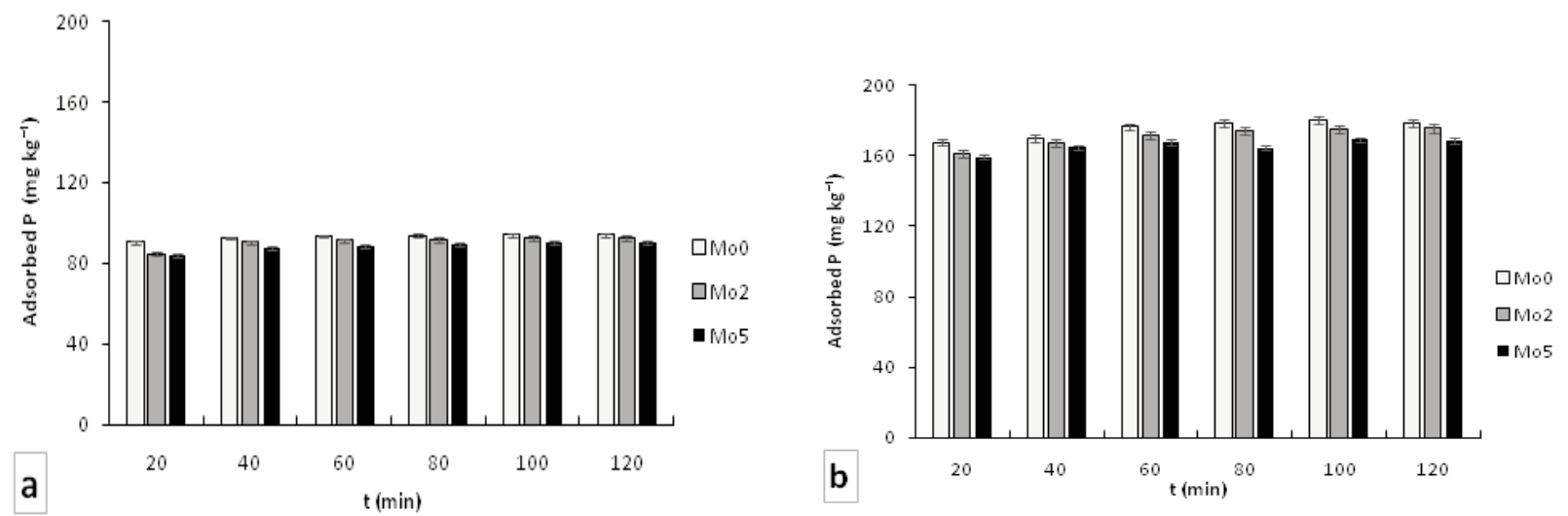

Figure 4. Effect of Molybdate persence on the phosphate adsorption in Typic Hapludult of Cigudeg. Bogor. Mo0 : absence of Molybdate; Mo2 : persences of Molybdate concentration of $2 \mathrm{mmol} . \mathrm{L}^{-1}$; Mo5 : persences of Molybdate concentration of 5 mmol. $\mathrm{L}^{-1}$. a) initial P of $1 \mathrm{mmol} . \mathrm{L}^{-1}$; b) initial P of $2 \mathrm{mmol} . \mathrm{L}^{-1}$.

for surface sites (Perassi and Borgnino, 2014). Organic matter like humic acid can increasing soil $\mathrm{pH}$ and forming strong complexes to controls the activity of $\mathrm{Al}$ and $\mathrm{Fe}$ in soil solution. The lowered $\mathrm{Al}$ and $\mathrm{Fe}$ activities will decrease the chelate or precipitation of $\mathrm{P}$ with these ions to increase availability phosphor for the plant (Ifansyah, 2013). Soil humic acid (SHA ) and $\mathrm{PO}_{4}$ generated electrostatic field and competition for adsorption sites were responsible for the mechanism by which SHA inhibited adsorption of PO4 as much as $27.8 \%$ by goethite (Fu et al., 2013).

The adsorption of $\mathrm{P}$ as a function of time are presented in Figures 3 and 4. The adsorption of phosphate increased with time. Figure 3 showed two clearly steps A fast initial reaction, $\mathrm{P}$ was quickly sorbed of $90.25 \mathrm{ppm}$ in 20 minute for about $95 \%$ from initial $\mathrm{P}$ concentrations $1 \mathrm{mmol} \cdot \mathrm{L}^{-1}$ and 167 ppm about $88 \%$ from initial $\mathrm{P}$ concentrations 2 mmol. $\mathrm{L}^{-1}$, followed by a slow adsorption (up to 24 h). It indicate the highly adsorption site in the soil. As independent, aplication of humic acid with rate of $100 \mathrm{mg} . \mathrm{L}^{-1}$ was not significantly affected to the adsorption of P. By T-test, there was not difference of $\mathrm{P}$ adsorption in the soil affected by humic acid at all time of adsorption in both initial $\mathrm{P}$ concentration (Table 2 and 3). Same case to the amorphous minerals, application of humic acid with rate of $100 \mathrm{mg} . \mathrm{L}^{-1}$, was not effective in decreasing $\mathrm{P}$ adsorption (Hanudin et al., 2014). Addition of humic and fulvic acids does not always decrease $\mathrm{P}$ adsorption in soils (Ohno and Crannell, 1996). In volcanic soils, the new humic acid-Al complex formed by adsorption of humic acid acts as a new source of $\mathrm{P}$ adsorption sites (Rengel, 2003). Metal in the form of oxides or hydroxydes can make complex with organic groups in humic acid, that has capacity to hold phosphate ions (Weir and Soper, 1963). Some studies have showed that increasing the organic matter content of 
Table 5. Effect of molybdate persence to the adsorption of phosphate by Typic Hapludult of Cigudeg, Bogor.

\begin{tabular}{ccccccc}
\hline $\begin{array}{c}\text { Concentration of } \\
\text { Mo in soil solution } \\
\left(\mathrm{mmol} \mathrm{L}^{-1}\right)\end{array}$ & 20 & 40 & 60 & 80 & 100 & 120 \\
\hline 0 & $167.5754 \mathrm{a}$ & $169.8985 \mathrm{a}$ & $176.3176 \mathrm{a}$ & $178.2622 \mathrm{a}$ & $180.1076 \mathrm{a}$ & $\left.178.2741 \mathrm{a}^{*}\right)$ \\
2 & $161.1088 \mathrm{a}$ & $167.0496 \mathrm{a}$ & $171.5469 \mathrm{ab}$ & $173.9901 \mathrm{a}$ & $175.1248 \mathrm{a}$ & $175.4432 \mathrm{ab}$ \\
5 & $159.2844 \mathrm{a}$ & $164.5678 \mathrm{a}$ & $167.4739 \mathrm{~b}$ & $164.3532 \mathrm{~b}$ & $168.8995 \mathrm{~b}$ & $168.3017 \mathrm{~b}$ \\
\hline
\end{tabular}

Remarks: *) Column values followed by the same letter are not significantly different according to Duncan's multiple range test $(\mathrm{P}=0.05)$

Table 6. Values of determination coefficient (R2) and standard error (SE) obtained from the model kinetic fitting to the experimental data for the adsorption of phosphate by Typic Hapludult of Cigudeg, Bogor.

\begin{tabular}{ccccccccc}
\hline \multirow{2}{*}{ Treatment } & \multicolumn{2}{c}{ Zero Order } & \multicolumn{2}{c}{ First Order } & \multicolumn{2}{c}{ Second Order } & \multicolumn{2}{c}{ Elovich } \\
\cline { 2 - 9 } & SE & R2 & SE & R2 & SE & R2 & SE & R2 \\
\hline P1 Mo0 & 39.770 & 0.279 & 0.111 & 0.876 & 0.001 & 1.000 & 0.464 & 0.918 \\
P1 Mo2 & 37.720 & 0.210 & 0.100 & 0.877 & 0.002 & 1.000 & 1.157 & 0.874 \\
P1 Mo5 & 37.200 & 0.237 & 0.057 & 0.854 & 0.001 & 1.000 & 0.637 & 0.931 \\
P2 Mo0 & 73.030 & 0.212 & 0.069 & 0.812 & 0.004 & 1.000 & 1.808 & 0.900 \\
P2 Mo2 & 70.570 & 0.189 & 0.039 & 0.941 & 0.002 & 1.000 & 0.844 & 0.982 \\
P2 Mo5 & 70.180 & 0.256 & 0.038 & 0.689 & 0.005 & 1.000 & 1.829 & 0.791 \\
H-P1 Mo0 & 39.840 & 0.290 & 0.140 & 0.652 & 0.004 & 1.000 & 0.506 & 0.867 \\
H-P1 Mo2 & 39.470 & 0.320 & 0.118 & 0.173 & 0.011 & 0.999 & 0.995 & 0.354 \\
H-P1 Mo5 & 38.330 & 0.312 & 0.049 & 0.419 & 0.006 & 1.000 & 0.604 & 0.634 \\
H-P2 Mo0 & 74.130 & 0.225 & 0.085 & 0.740 & 0.002 & 1.000 & 2.092 & 0.869 \\
H-P2 Mo2 & 72.040 & 0.246 & 0.084 & 0.411 & 0.006 & 0.999 & 3.348 & 0.647 \\
H-P2 Mo5 & 69.410 & 0.238 & 0.066 & 0.788 & 0.008 & 0.999 & 2.238 & 0.747 \\
\hline
\end{tabular}

soil does not decrease adsorption of $\mathrm{P}$, however, suggest that organic matter affects the binding energy of adsorbed $\mathrm{P}$ and possibly as a result of phosphate adsorption with little energy by cation bridges, therefore increase the availability of phosphate (Fiona R., Dean and James, 2010).

There is interaction of phosphorus with molybdenum in the soil that affects availability both of phosphorus or molybdenum (Kopsell, Kopsell and Hamlin, 2015). Phosphate strongly competed with molybdate (Roy, Hassett and Griffin, 1986) for adsorption siteson the Andisols, causing molybdate adsorption to decrease by $10-27 \%$ (Vistoso et al., 2012). The competition also was showed by (Sun and Selim, 2017) that amount of Mo sorbed decreased substantially with increasing P concentration, which indicates that $\mathrm{P}$ has a competitive effect for available adsorption sites. As independent, persence of Molybdate significantly affected to the adsorption of P (Table 4 and 5). Persence of molybdate 2 and 5 mmol. $\mathrm{L}^{-1}$ decrease $\mathrm{P}$ adsorption significantly in both initial P concentration of 1 and 2 mmol. $\mathrm{L}^{-1}$ about 1.5$8 \%$. Higher concentration of Molybdate persence in the solution will reduceadsorbed $P$ in the soil, suggesting strong competition between the two anions. At high concentrations phosphorus was more effective in inhibiting molybdate adsorption (Vistoso et al., 2012), and ofcourse similarly thehigh concentrations molybdate was more effective in inhibiting phosphorus adsorption.

The adsorption of phosphate increased with time. Phosphate adsorption patern showed two steps as mentiones before, fast initial adsorption (up to 20 minutes), followed by a slow adsorption. The similar results were obtained by (Zeng et al., 2003); (Vistoso et al., 2009); (Vistoso et al., 2012) for the adsorption of phosphate by Andisols and for the adsorption of phosphate by on goethite (Luengo et al., 2006). Four different kinetics models using the least square regression analysis was tested to describe the adsorption of phosphate in the Typic Hapludult (Table 6). Accordance model determined by correlate the experimenral data with the linear models of the four models, respectively. Zero order kinetics models gave very low value of determination coefficients $\left(\mathrm{R}^{2}\right)$ in range $0.189-0.320$ with high difference between experimental and theoretical adsorbed phosphates at equilibrium (SE) is very high between 37.20 and 74.13. The model and the experimental data show a bad fit. So the adsorption of phosphates onto Typic Hapludult is not ideal ilustrated with zero order kinetics models. The first order kinetics model gave value of 
P1 MoO

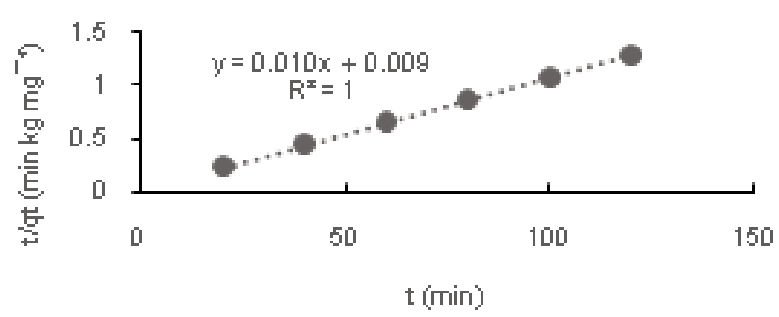

P1 Mo5

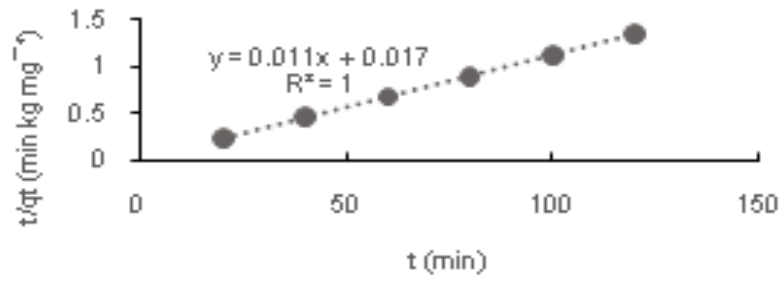

$\mathrm{P} 2 \mathrm{Mo} 2$

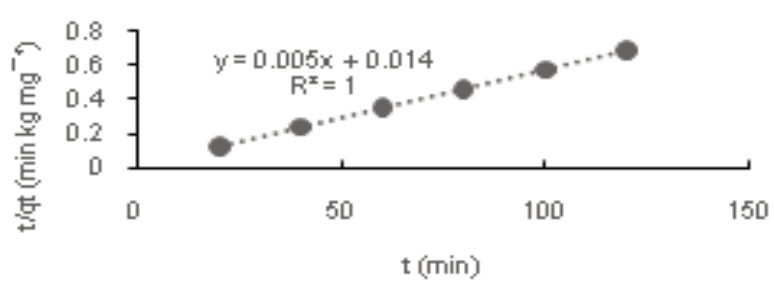

P1 Mo2

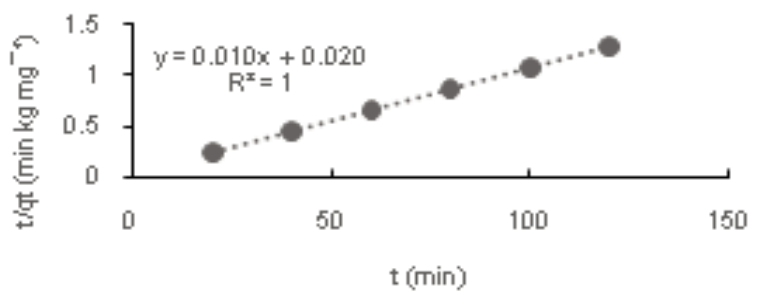

$\mathrm{P} 2 \mathrm{MOO}$

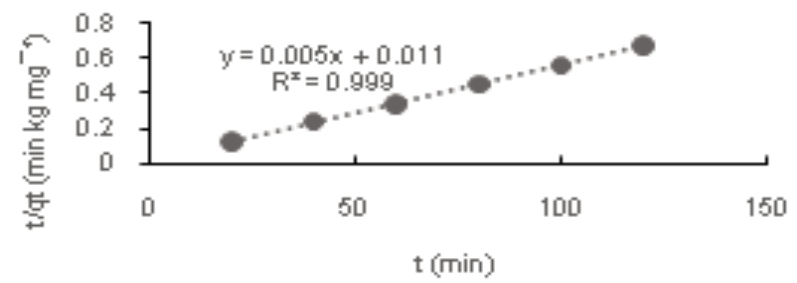

P2 Mo5

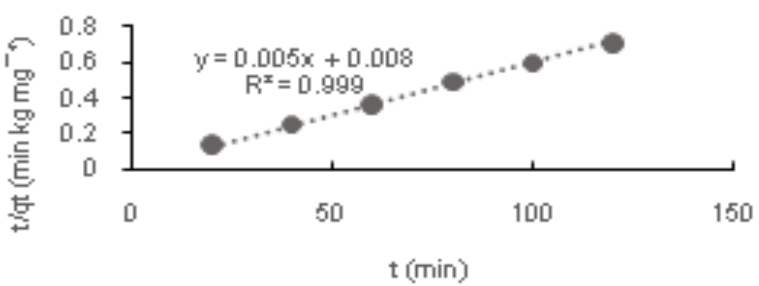

Figure 5. The second order plot for adsorption of $\mathrm{P}$ affected by Molybdate in Typic Hapludult of Cigudeg, Bogor. correlation coefficients are relatively low lying between 0.411 and 0.941. Difference between experimental and theoretical adsorbed phosphate at equilibrium is very high about 0.055-0.199. These results also state a bad fit between the model and the experimental data. So the first order kinetics model is not ideal for adsorption of phosphates onto Typic Hapludult. For the second order kinetics model, the determination coefficients for all treatment are higher than 0.99 with value $0.999-1$. The difference between the experimental and theoretical adsorbed phosphateat equilibrium is very small (less than $1 \%$ ) with value of 0.001-0.011. Meanwhile Elovich kinetics model show variable range value of determination coefficients between 0.354 and 0.982. Difference between experimental and theoretical adsorbed phosphate at equilibriumis very high about $0.506-3.348$. From four kinetics models, the second order kinetics models apropriate to the adsorption $\mathrm{P}$ in the acid soil, according to (Otero et al., 2013) that second order kinetic model gave an appropriate description of $\mathrm{PO}_{4}-\mathrm{P}$ adsorption onto estuarine sediments and onto the upstream agricultural soils. But was different to the (Vistoso et al., 2012); (Zeng et al., 2003) that found that the adsorption of phosphate could not be adequately described by a zero, first, or second order kinetic model.

The second order kinetics models parameters for the adsorption of phosphate are listed in Table 7. The second order kinetics models gave the best determination coefficients $\left(\mathrm{R}^{2}\right)$ value, both without and with humic acid treatment, close to perfect value of 1 with 
Table 7. Values of the parameters $\left(q_{e}\right.$ and $\left.k_{2}\right)$ derived from fitting the experimental data for the adsorption of phosphate in Typic Hapludult of Cigudeg. Bogor to the second order kinetics model.

\begin{tabular}{ccccc}
\hline Treatment & $1 / q_{e}$ & $q_{e}$ & $1 / k_{2} q_{e}{ }^{2}$ & $k_{2}$ \\
\hline P1 Mo0 & 0.0105 & 94.8017 & 0.0099 & 0.0112 \\
P1 Mo2 & 0.0106 & 94.0517 & 0.0207 & 0.0055 \\
P1 Mo5 & 0.0110 & 91.1893 & 0.0175 & 0.0069 \\
P2 Mo0 & 0.0055 & 182.4482 & 0.0117 & 0.0026 \\
P2 Mo2 & 0.0056 & 179.3049 & 0.0143 & 0.0022 \\
P2 Mo5 & 0.0059 & 170.2031 & 0.0085 & 0.0041 \\
H-P1 Mo0 & 0.0106 & 94.1676 & 0.0077 & 0.0146 \\
H-P1 Mo2 & 0.0110 & 90.9805 & 0.0005 & -0.2416 \\
H-P1 Mo5 & 0.0112 & 89.1521 & 0.0035 & 0.0359 \\
H-P2 Mo0 & 0.0055 & 182.6555 & 0.0087 & 0.0034 \\
H-P2 Mo2 & 0.0057 & 174.4862 & 0.0063 & 0.0052 \\
H-P2 Mo5 & 0.0058 & 171.6136 & 0.0131 & 0.0026 \\
\hline
\end{tabular}

low SE value. It was according to the (Huang et al., 2015) in phosphate adsorption by $\mathrm{Zr} / \mathrm{Al}-\mathrm{Mt}$ and (Zhang et al., 2015) that second order kinetic model more suitable for describing the adsorption behavior of phosphorus in soils. The amount of phosphates sorbed at equilibrium (qe) was affected by persence concentration of molybdate but not by the persence of humic acid in the soil solution. The equilibrium adsorption capacity (qe) increases as the higher initial phosphate concentration in the soil solution. Further, it was found that the variations value of the rate constant $\left(k_{2}\right)$ that not affected by persence concentration of molybdate and the persence of humic acid in the soil solution.

\section{CONCLUSION}

Humic acid with contain of $54 \% \mathrm{C}$ and $3.1 \% \mathrm{~N}$, shows that lots of hydroxyl and carboxylic groups exist in humic acid, with strong absorption at 3425 $\mathrm{cm}^{-1}, 2,924 \mathrm{~cm}^{-1}, 2,855 \mathrm{~cm}^{-1}, 1651 \mathrm{~cm}^{-1}$ and no absorption in $1000 \mathrm{~cm}^{-1}$ in FTIR. As ststistically, application of humic acid with rate of $100 \mathrm{mg} . \mathrm{L}^{-1}$ was not effective in decreasing $\mathrm{P}$ adsorption in acid soil. Identification by $\mathrm{X}$-ray diffraction of the soil show some characteristics, the soil contain of kaolinite and metahalloysite minerals, also contain of gibbsite, goethite and hematite as oxides and hydroxides and feldspar as silicates minerals. Mineral contents are according to the soil analysis i.e. acidic soil $\mathrm{pH}$, low moderate CEC, and low base saturation. Meanwhile aplication 2 and $5 \mathrm{mmol} . \mathrm{L}^{-1}$ of molybdenum significantly affected $\mathrm{P}$ adsorption. The adsorption of phosphate increased with time. Phosphate adsorption patern showed two steps, fast initial adsorption (before 20 minutes), followed by a slow adsorption. The secondorder kinetics model gave determination coefficients $\left(\mathrm{R}^{2}\right)$ for all treatment with value 0.999 1. The difference between the experimental and theoretical (SE) adsorbed phosphate at equilibrium is very small (less than $1 \%$ ) with value of 0.001 0.011. Meanwhile Elovich kinetics model show variable range value of determination coefficients $\left(\mathrm{R}^{2}\right)$ between 0.354 and 0.982 . Difference between experimental and theoretical adsorbed phosphate at equilibrium (SE) is very high about 0.506-3.348. From four kinetics models, the second order kinetics models apropriate to the adsorption $\mathrm{P}$ in the Typic Hapludult of Cigudeg, Bogor.

\section{ACKNOWLEDGEMENT}

We would like to thank to Indonesian Agency for Agricultural Research and Development, Ministry of Agriculture for funding this research. We are deeply indebted to all of Soil Science Laboratory members, Universitas Gadjah Mada for their help during laboratory works.

\section{REFERENCES}

Anwar, S. and Sudadi, U. 2013. Kimia Tanah empat. Bogor: Departemen Ilmu Tanah dan Sumberdaya Lahan Fakultas Pertanian, Institut Pertanian Bogor.

Badan Penelitian dan Pengembangan Pertanian. 2014. Peta Sumber Daya Tanah Tingkat Semi Detail Kabupaten Bogor Provinsi Jawa Barat. Bogor: Badan Penelitian dan Pengembangan Pertanian Kementerian Pertanian. http://bbsdlp.litbang.pertanian.go.id/ind/index.php/laya nan-mainmenu-65/produk/532-peta-tanahskala-1-50-000.

Balai Penelitian Tanah.2009. Petunjuk Teknis Analisis Kimia Tanah, Tanaman, Air, Dan Pupuk. $2^{\text {nd }}$ ed. Bogor: Balai Penelitian Tanah.

Chotzen, R. A., Polubesova, T., Chefetz, B. and Mishal, Y. G. 2016. Adsorption Of Soil-Derived Humic Acid By Seven Clay Minerals : A Systematic Study. 64 (5): 628-638. doi: 10.1346/CCMN.2016.064027.

Dong, Y. L. 2016. Adsorption Kinetics of SoilExchangeable $\mathrm{Zn}$ and Mn by Fe-Al Binary Oxide, in Chen, P. (ed.) Material Science and Engineering. Netherlands: CRC Press Taylor \& Francis Group, 101-104.

Fiona R., K., Dean, H. and James, M. 2010. Phosphate sorption to organic matter/ferrihydrite systems as affected by aging time. 19th World Congress 
of Soil Science, Soil Solution for a changing World, (August), 84-87. Available at: http://www.iuss.org/19 ${ }^{\text {th }}$ WCSS/Symposium/pdf/2465.pdf.

Fu, Z., Wu, F., Song, K., Lin, Y., Bai, Y., Zhu, Y. and Giesy, J. P. 2013. Competitive interaction between soil-derived humic acid and phosphate on goethite. Applied Geochemistry. 36: 125131. doi: 10.1016/j.apgeochem.2013.05.015.

Hanudin, E., Sukmawati, S. T., Radjagukguk, B. and Widya, N. 2014. The Effect of Humic Acid and Silicic Acid on P Adsorption by Amorphous Minerals. Procedia Environmental Sciences. 20:402-409. doi: 10.1016/j.proenv.2014.03.051.

Huang, W., Chen, J., He, F., Tang, J., Li, D., Zhu, Y. and Zhang, Y. 2015. Effective phosphate adsorption by $\mathrm{Zr} / \mathrm{Al}$-pillared montmorillonite: Insight into equilibrium, kinetics and thermodynamics. Applied Clay Science. 104: 252-260. doi: 10.1016/j.clay.2014.12.002.

Ifansyah, H. 2013. Soil pH and Solubility of Aluminum, Iron, and Phosphorus in Ultisols : the Roles of Humic Acid. Journal of Tropical Soils. 18(3): 203-208. doi: 10.5400/jts.2013.18.3.203.

IHSS. (no date). Isolation of IHSS Soil Fulvic and Humic Acids IHSS. Available at: http://humic-substances.org/isolation-of-ihsssoil-fulvic-and-humic-acids/ (Accessed: 4 November 2017).

IUSS Working Group WRB. 2014. World reference base for soil resources 2014. International soil classification system for naming soils and creating legends for soil maps, World Soil Resources Reports No. 106. Rome: Food and Agriculture Organization Of The United Nations. doi: 10.1017/S0014479706394902.

J. Benton Jones, J. 2012. Plant Nutrition and Soil Fertility Manual. second edi. CRC Press Taylor \& Francis Group.

Kopsell, D. A., Kopsell, D. E. and Hamlin, R. L. 2015. Molybdenum, in Barker, A. V. and Pilbeam, D. J. (eds) Handbook of Plant Nutrition. $2^{\text {nd }}$. CRC Press. pp 487-510.

Kurnain, A. 2016. Inhibition of phosphorus adsorption to goethite and acid soil by organic matter. International Journal of Soil Science. 11(3): 87-93. doi: 10.3923/ijss.2016.87.93.

Luengo, C., Brigante, M., Antelo, J. and Avena, M. 2006. Kinetics of phosphate adsorption on goethite: Comparing batch adsorption and ATR-IR measurements. Journal of Colloid and Interface Science. 300 (2): 511-518. doi: 10.1016/j.jcis.2006.04.015.

Maccarthy, P. and Rice, J. A. 1985. Spectroscopic Methods (Other Than NMR) for Determining
Functionality in Humic Substances, in Humic Substances In Soil, Sediment, And Water Geochemistry, Isolation, and Characterization. Canada: John Wiley \& Sons, Inc. 528-260.

Mengel, K., Kirkby, E. A., Kosegarten, H. and Appel, T. 2001. Principles of Plant Nutrition. $5^{\text {th }}$ edn. Springer-Science+Business Media, B. V. doi: 10.1007/978-94-010-1009-2.

Ohno, T. and Crannell, B. S. 1996. Green and Animal Manure-Derived Dissolved Organic Matter Effects on Phosphorus Sorption. Journal of Environmental Quality. 25: 1137-1143. doi: 10.2134/jeq1996.00472425002500050029x.

Otero, M., Coelho, J. P., Rodrigues, E. T., Pardal, M. A., Santos, E. B. H., Esteves, V. I. and Lillebø, A. I. 2013. Kinetics of the $\mathrm{PO}_{4}-\mathrm{P}$ adsorption onto soils and sediments from the Mondego estuary (Portugal). Marine Pollution Bulletin. 77(1-2): 361-366. doi: 10.1016/j.marpolbul.2013.08.039.

Pansu, M. and Gautheyrou, J. 2006. Handbook of Soil Analysis Mineralogical, Organic and Inorganic Methods. Netherlands: SpringerVerlag Berlin Heidelberg. doi: 10.1007/9783-540-31211-6.

Perassi, I. and Borgnino, L. 2014. Adsorption and surface precipitation of phosphate onto $\mathrm{CaCO}_{3}$-montmorillonite: Effect of $\mathrm{pH}$, ionic strength and competition with humic acid. Geoderma. 232-234: 600-608. doi: 10.1016/j.geoderma.2014.06.017.

Rengel, Z. 2003. Handbook of Soil Acidity. Marcel Dekker, Inc. 270 Madison Avenue, New York, NY 10016. doi: 10.1201/9780203912317.

Roy, W. R., Hassett, J. J. and Griffin, R. A. 1986. Competitive Coefficients for the Adsorption of Arsenate, Molybdate, and Phosphate Mixtures by Soils. Soil Science Society of America Journal. 50: 1176-1182. doi: $10.2136 /$ sssaj 1986.03615995005000050017x.

Sparks, D. L. 2012. Kinetics and Mechanisms of Soil Chemical Reactions Donald, in Huang, P. M., Li, Y., and Malcolm, S. E. (eds) Handbook of Soil Sciences: Properties and Processes. Second Edi. CRC Press Taylor \& Francis Group, pp. 1-30. doi: DOI: 10.13140/2.1.3758.1120.

Steelink, C. 1985. Implications of Elemental Characteristics of Humic Substances, in G. R. Aiken, McKnight, D. M., Wershaw, R. L., and MacCarthy, P. (eds) Humic Substances in Soil, Sediment, and Water. Geochemistry, Isolation, and Characterization. Canada: John Wiley \& Sons, Inc. 457-476.

Sun, W. and Selim, H. M. 2017. Molybdenum-phosphate retention and transport in soils. Geoderma. 
8: 60-68. doi: 10.1016/j.geoderma.2017.08.031.

Tan, K. H. 2011. Principles of Soil Chemistry. 4 th. United States of America: CRC Press Taylor \& Francis Group.

Tan, K. H. 2014. Humic Matter in Soil and the Environment: Principles and Controversies, Second Edition. 2 nd. New York: CRC Press Taylor \& Francis Group 6000 Broken Sound Parkway NW, Suite 300 Boca Raton, FL 33487 2742.

USDA. 2014. Keys to Soil Taxonomy. 12 th. United States Department of Agriculture Natural Resources Conservation Service.

Vistoso, E. M., Bolan, N. S., Theng, B. K. G. and Mora, M. de la L. 2009. Kinetics Of Molybdate And Phosphate Sorption By Some Chilean Andisols. Journal Soil Science and Plant Nutrition, 9(1): 55-68.

Vistoso, E., Theng, B. K. G., Bolan, N. S., Parfitt, R. L. and Mora, M. L. 2012. Competitive sorption of molybdate and phosphate in Andisols. Journal of Soil Science and Plant Nutrition. 12(1): 59-72.

Weir, C. C. and Soper, R. J. 1963. Interaction of
Phosphates With Ferric Organic Complexes. Canadian Journal of Soil Science. 43: 393399.

Zeng, L., Johnson, R. L., Li, X. and Liu, J. 2003. Phosphorus removal from aqueous solutions by sorption on two volcanic soils. Canadian Journal of Soil Science. 83(5): 547-556. doi: 10.4141/S03-006.

Zhang, L., Loáiciga, H. A., Xu, M., Du, C. and Du, Y. 2015. Kinetics and mechanisms of phosphorus adsorption in soils from diverse ecological zones in the source area of a drinking-water reservoir. International Journal of Environmental Research and Public Health. 12(11): 4312-14326. doi: 10.3390/ijerph121114312.

Zhenghua, W., Jun, L., Hongyan, G., Xiaorong, W. and Chunsheng, Y. 2001. Adsorption isotherms of lanthanum to soil constituents and effects of $\mathrm{pH}$, EDTA and fulvic acid on adsorption of lanthanum onto goethite and humic acid. Chemical Speciation and Bioavailability. 13(3): 75-81. doi: $10.3184 / 095422901782775444$ 